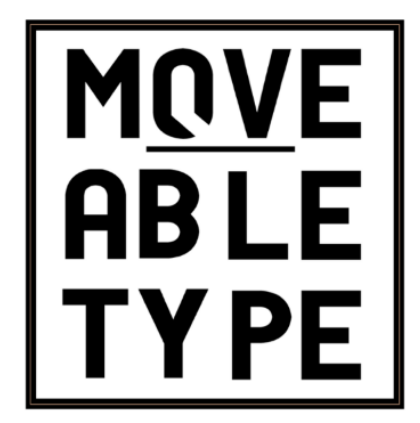

Article: The Fisher, The Spear, and the Fortunate Fish: Premature and Dissolving Endings in Shelley's Poetry

Author[s]: Julia Tejblum

Source: MoveableType, Vol. 7, 'Intersections' (2014)

DOI: $10.14324 / 111.1755-4527.059$

MoveableType is a Graduate, Peer-Reviewed Journal based in the Department of English at UCL.

(C) 2014 Julia Tejblum. This is an Open Access article distributed under the terms of the Creative Commons Attribution License (CC-BY) 4.0https://creativecommons.org/licenses/by/4.0/, which permits unrestricted use, distribution, and reproduction in any medium, provided the original author and source are credited.

\title{
UCLPRESS
}




\section{The Fisher, the Spear, and the Fortunate Fish: \\ Premature and Dissolving Endings in Shelley's Poetry}

Walter Benjamin famously observed that our interest in narrative is bound up not only with our in-

terest in life, but, more tellingly, with our interest in death: we hope to learn something of the meaning

of our own lives from the lives of fictional characters, but much of that meaning is revealed to us only

through our witnessing the character's death. The revelation of meaning through death, which Ben-

jamin likens to catching the heat of a flame, is impossible without fiction, since none of us survives our

own death and, therefore, none can take part in the revelation unless it is at the expense of another:

"What draws the reader to the novel is the hope of warming his shivering life with a death he reads

about." But Benjamin's observations go beyond the sphere of the novel; a curiosity about any narrative

ending is a curiosity about death. Likewise, Frank Kermode describes how poets attempt to answer the

human "need in the moment of existence to belong, to be related to a beginning and an end."² But how

can these temporal theories be reconciled with endings which look beyond death?

This paper will examine the ways in which Percy Bysshe Shelley subverts certain temporal

characteristics of narrative in his poetry, like those upon which Benjamin's and Kermode's theories

rely, and creates endings which never feel quite right. Tracking the various types of anticlimax these

endings produce, it will also argue that, in his achronological narrative and poems which dissolve

1 Walter Benjamin. "The Storyteller.” Illuminations. Trans. Harry Zohn (New York: Schocken Books, 1969) p.91.

2 Kermode, Frank. The Sense of an Ending: Studies in the Theory of Fiction (New York: Oxford University Press, 1967) p.4. 
rather than end, Shelley works out a dissatisfaction with a narrative trajectory that does not seem true

to him. For Shelley, the revelation of the ending does not come to us in death; thought and understanding (and poetry) do not move at the same pace as life, and this tragic disjunction complicates his thinking about the end of the poem. Starting with Shelley's clearest narrative, the conversational poem "Julian and Maddalo," moving through several short lyrics and, finally, to his last poems, "Lines Written in the Bay of Lerici” and "The Triumph of Life," this paper will establish a pattern of anticlimax in Shelley's poetry, in which the narrator continually outlives the end of his poems.

\section{The "Ineffectual Angel:" Shelley's Dissatisfied Critics}

Timothy Webb begins his book-length study of Shelley's poetic career with an anecdote recorded by

Shelley's friend Edward Trelawney, in which Shelley nearly drowns. ${ }^{3}$ While watching his friend per-

form impressive aquatic maneuvers in the Arno, Shelley bemoans his own inability to swim. Tre-

lawney urges Shelley to try this easy, natural activity, and eventually convinces him to dive into the

river. But Shelley does not learn to swim; he immediately sinks to the bottom, and, curiously, remains

there with no effort to save himself. After a panicked Trelawney dives down to retrieve Shelley, saving

the life of his famous friend, Shelley calmly explains his behavior:

I always find the bottom of the well, and they say Truth lies there. In another minute I should have found it, and you would have found an empty shell. It is an easy way of getting rid of the body. ${ }^{4}$

3 For the original account, see Edward Trelawney. Records of Shelley, Byron, and the Author, Ed. David Wright (Harmondsworth: Penguin, 1973) p.106. For Timothy Webb's treatment of the anecdote, see Shelley: A Voice Not Understood (Manchester: Manchester University Press, 1977) p.1-2.

4 Trelawney, Records of Shelley, Byron, and the Author, p.106. 
While Webb relates this anecdote in aid of a discussion of Shelley critics' and biographers' par-

ticular susceptibility to legends about the poets' life- this one, he contends, is almost certainly fabric-

ated - the anecdote highlights an important feature of these legends, and, indeed, of Shelley's critical

heritage. There is an extent to which critics, from Shelley's contemporaries to modern scholars, associ-

ate Shelley with a doomed quest for truth, or an ill-fated, lofty ambition not only for poetry, but for

man. ${ }^{5}$ Few critics deny Shelley's greatness, but many deny his ultimate success in carrying out his pro-

jects. There seems to exist in this critical tendency a sort of final disappointment, a sense that Shelley's

whole pursuits - a completed poem or even the entire body of his work after his death - let down the

promise of their component parts.

In his review of Shelley's Posthumous Poems, William Hazlitt comments on the whole of Shel-

ley's poetic achievement:

Mr Shelley is to poetry what astrology is to natural science- a passion-

ate dream, a straining after impossibilities, a record of fond conjectures, a confused embodying of vague abstractions, - a fever of the soul, thirsting and craving after what it cannot have, indulging its love of power and novelty at the expense of truth and nature, associating ideas by contraries, and wasting great powers by the application to unattainable objects. ${ }^{6}$

5 See especially Matthew Arnold's famous declaration that Shelley was "a beautiful and ineffectual angel, beating in the void his luminous wings in vain." Matthew Arnold, Essays in Criticism, Second Series (London: MacMillan, 1888) pp.205-252; and William Hazlitt's remarks on his poetic achievement in his "Review of Shelley's Posthumous Poems." Edinburgh Review (July 1824, Vol XI) pp.494-514.

6 Hazlitt, "Review of Shelley’s Posthumous Poems", p.494. 
Each of Hazlitt's criticisms suggests a poet who could not make his endings work; his subjects remain “impossibilities," his ideas "conjectures," and his images only "vague abstractions;" Shelley wastes his powers by failing to attain what he seeks. While Hazlitt seems to suggest that the problem lies more with the impossibility of the subject matter than with the powers of the poet, it cannot be denied that these attacks have to do with a perceived failure on Shelley's part to reconcile, isolate, or conclude the problems or situations he creates within his poetry. While this is an easy trend to notice among Shelley's critics, few of these critics devote extended attention to the actual endings of Shelley's poems. ${ }^{7}$

Sustained attention to Shelley's endings, in both poems which conclude and those which simply trail off, may help to shed light on a critical generalization which, though frequently contested, makes an appearance in most critical studies of the poet. A study of Shelley's endings may also help to distinguish between different notions of what a poem's ending is meant to do, or what effect that ending is meant to have upon both the reader and the poem's inspiration or theme. ${ }^{8}$

\section{"The cold world shall not know:" Optimism and Anti-Climax in "Julian and Maddalo"}

Among the poems which appear in Shelley’s Posthumous Poems, Hazlitt chooses "Julian and

Maddalo" as a representative of "that veil of shadowy or of glittering obscurity, which distinguished Mr

7 Harold Bloom provides an excellent account of Shelley's critical reception, from his immediate reviews to his reemergence in the middle of the twentieth century as a poet of great merit. "Shelley's Reputation Before 1960: A Sketch" Shelley's Poetry and Prose (New York: W.W. Norton, 2002) Second Edition. pp.539-549.

8 For a broad study of poetic endings, see Barbara H. Smith, Poetic Closure: A Study of How Poems End, (Chicago: University of Chicago Press, 1968). Smith categorizes ending devices, and includes Shelley's "Hellas" among those poems which end with what she calls "closural allusions," in which words like "cease," "no more," "last," and "rest" signify termination. 172; J. Hillis Miller contends that the notion of ending "is inherently undecidable." "The Problematic of Ending in Narrative" Nineteenth-Century Fiction, Vol. 33.1 1978. p.3. 
Shelley's writings."9 As several critics have noted, "Julian and Maddalo" does not resemble any of Shel-

ley's other works. The poem, which Shelley called "a conversation," is a narrative poem in the plainest

sense; Shelley told Leigh Hunt that he endeavored to write a poem in the style of a real conversation

between two educated people of refined sentiment, without the use of idioms. ${ }^{\circ}$ But Earl Wasserman

hears Byron's "urbane poetic talk” in Shelley's language, which he compares to the conversational style

of "Hamlet"'s Horatio. " Shelley's preface reveals more about the characters than it does about the plot,

although of the Maniac it gives "no information."

Shelley's editors have determined that "Julian and Maddalo" was at least partly based upon a

real outing and conversation Shelley had with Byron on August 23rd, I 8 I 8. ${ }^{12}$ Shelley gives an account

of this day with Byron in a letter to his wife, Mary, but this letter says nothing of the topics about which

Julian and Maddalo speak in the poem. While the setting is the same-Shelley writes to Mary of a gon-

dola ride to a "long sandy island," and a ride along the sea filled with conversation-the real conversa-

tion took a more personal turn:

Our conversation consisted in histories of his wounded feelings, \& questions as to my affairs, \& great professions of friendship \& regard for me. He said that if he had been in England at the time of the Chancery affair [a court decision which had recently deprived Shelley of custody over his children by his first wife, now deceased], he would have moved Heaven \& Earth to have prevented such a decision. We talked of literary matters, his fourth Canto which he says is very good, \& indeed repeated some stanzas of great energy to me. ${ }^{\mathrm{I}}$

9 Hazlitt, "Review of Shelley's Posthumous Poems", p.496.

10 The Letters of Percy Bysshe Shelley, Ed. Frederick L. Jones (Oxford: Clarendon Press, 1964), II. 108.

11 Earl R. Wasserman, Shelley: A Critical Reading (Baltimore: Johns Hopkins University Press, 1971), p.57. 12 Shelley's Poetry and Prose, eds. Donald H. Reiman and Neil Fraistat (New York: W.W. Norton \& Company, 2002), p.121 n.1.

13 The Letters of Percy Bysshe Shelley, III. 36-37. 
While the gondola, the island, and the ride along the beach all make appearances in the real scene, nothing of the conversation Shelley reports to his wife suggests the conversational dynamic of "Julian and Maddalo." In the poem, Shelley's Julian argues “against despondency” while Byron’s Maddalo "take[s] the darker side (48-49). ${ }^{14}$ In their real conversation, both discuss past wrongs, current work, and their own friendship.

What does appear in both Shelley's letter and his poem is a sense that Shelley, and his poetic avatar, Julian, are continually frustrated by interruptions. If, as R.D. Havens suggests, we consider "Julian and Maddalo” as being composed of three parts—-the conversation between Julian and Maddalo before they journey to the madhouse, their voyage and the madman's speech, and Julian's return to Venice many years later ${ }^{15}$-we can isolate three moments of in-conclusion caused by interruption with the poem itself. In the first part, as Julian begins to defend his “aspiring theories” against Maddalo's cynicism, his speech is cut short by the arrival of the gondola, and their attention arrested by the "fierce yells and howlings" (2 I 6) coming from within the madhouse. Following the second part of the poem, the madman's speech, which Shelley sets up to provide some resolution to the argument between the two, ceases abruptly. But Julian and Maddalo do not press the madman further, nor do they reflect upon its implications for the argument. They leave in haste, their "argument quite forgot" (520).

14 All quotations from Shelley's poetry and prose are taken from Shelley's Poetry and Prose, eds. Donald H. Reiman and Neil Fraistat (New York: W.W. Norton \& Company, 2002), Second Edition. 15 Raymond D. Havens, “Julian and Maddalo." Studies in Philology, Vol. 27, No. 4. (October 1930): pp.648-653. 
This same recurrence of interruption plagues Shelley in reality as he composes his letter: one conversation concerning the custody of a child is interrupted by a gondola ride, which Shelley took "much against my will for I wanted to return" to the situation at hand. ${ }^{16}$ Shelley concludes this letter, which he wrote in parts over the course of a single day, with a complaint: "Do you know dearest how this letter was written-by scraps \& patches \& interrupted every minute." He must conclude this correspondence, once again, because "the gondola is now come." ${ }^{17}$

Within the poem itself, Shelley, as Julian, acts as a kind of a pursuer of an ending. Julian, in contrast to Byron's cynical and jaded Maddalo, repeatedly asserts the optimistic potential of the mind:

"I love all waste /And solitary places," he narrates at the start of the poem, "where we taste / The pleasure of believing what we see / Is boundless, as we wish our souls to be” ( I 4-I 7). Julian repeats what Maddalo calls his “aspiring theories” (2०I) the following morning when he refutes Maddalo’s claim that man is "a passive thing" who must wait for "the night of death" to sever "Our memory from itself" (I27-I 30):

We might be otherwise--we might be all We dream of happy, high majestical.

Where is the love, beauty and truth we seek

But in our mind? ( I 72-I 75).

Maddalo's description of night severing "our memory from itself" anticipates the disjunction of the poem's conclusion, in which everyone besides Julian and Allegra has vanished-the Maniac is dead,

16 The Letters of Percy Bysshe Shelley, III. 36. The letter itself is interrupted; we do not know what happened upon Shelley and Byron's return to the latter's palace because a section of this page of the letter is missing.

17 Ibid., p.38. 
Maddalo is traveling far away, and even Maddalo's dog, which is never mentioned in the earlier scenes of the poem, is dead.

The poem, along with the circumstances of its composition, reaches no resolution. It is Allegra, and not Shelley, who ends "Julian and Maddalo" by insisting upon a stopping point:

If thine aged eyes disdain to wet Those wrinkled cheeks with youth's remembered tears, Ask me no more, but let the silent years Be closed and ceared over their memory As yon mute marble where their corpses lie (6 I I-6 I 4).

But the ending of "Julian and Maddalo" becomes stranger when we take into account the biographical aspects it invents: this future scene, in which Julian returns to Italy to find out "how all happened," is an imagined future. Byron's daughter Allegra, accurately depicted in the first part of the poem as a baby with whom Shelley played, died in I 822, at five years old. Although Shelley did not know that Allegra would not reach adulthood, this fact calls attention to the narration of the poem. The poem begins with a remembered scene: "I rode one evening with Count Maddalo" ( I). It is impossible to tell, until the poem's end, where this narrator is situated within time. The first part of the poem does not bear the marks of a long forgotten tale, and yet the narrator admits at the end of the poem that "many years and many changes" have passed since the conversation occurred (583). 
Even Allegra struggles to recall the intervening years, but she provides Julian with the struc-

ture of events since his departure: the Maniac's lady returned, and they lived for a time in Byron's

palace, and then they parted once more. Julian questions her to tell him the particulars, "why they parted, how they met" (6 г o)-a series of questions that will reappear in "The Triumph of Life"-but she refuses. Julian, who "urged and questioned still," convinces Allegra to tell him "how / All happened," but refuses to include it in the narration (6 I 6-6 I 7). Only fictional characters can know unknowable truths; it is possible that, while Julian finds out how all happened, Shelley does not.

\section{"Deep night / Caught them ere evening:" Time out of Joint}

Hazlitt laments that Shelley's poetry is "abortive. . f from aiming to be more than it is." ${ }^{18}$ In Hazlitt's formulation, Shelley's limitless expectations for the potential of an idea destroys that idea preemptively. But Hazlitt's criticism evokes a strange tendency in Shelley's poetry, by which a thing is destroyed before its end. One particular ending will serve as the characteristic example of this tendency in Shelley's poetry. In the final lines of Shelley's "Lines written in the Bay of Lerici," Shelley veers away from the poem's subject, his love of Jane Williams, and watches a spear-fisherman at work on the edge of the bay:

The fisher with his lamp And spear, about the low rocks damp Crept, and struck the fish who came

18 Hazlitt, "Review of Shelley's Posthumous Poems", p.494. 
To worship the delusive flame:

Too happy, they whose pleasure sought

Extinguishes all sense and thought

Of the regret that pleasure [leaves]

Destroying life alone not peace ( $5 \mathrm{I}-58)$

In Shelley's formulation, the happiness of the fish lies in the manner in which their revery is preserved; they do not experience an end brought about by disillusionment, an end which is characterized by the fact that it is not the end. The alternative narrative that lies behind the early death of the fish is one in which the fish reach their object of desire, the flame within the lamp, and nothing happens. This "regret that pleasure leaves," the regret which comes from obtaining an object of desire, distinguishes between two types of anti-climactic endings. There is the anticlimax of early death or extinguishment, which comes before the object of desire can be approached, and the anticlimax of finally possessing the object of desire, and finding that it was delusive. The fish experience a pure extinguishing, while Shelley, in the poem's earlier lines, attempts and fails to sustain a revery in which he can keep the pleasure of an encounter with Jane Williams alive through memory and fancy. The revery fails when memory fails, and the sights and sounds of reality outmatch the haunting echoes of her remembered words.

Throughout much of his poetry, Shelley is both fascinated and confounded by the regret that replaces pleasure experienced and lost, along with the particular happiness that accompanies the pursuit and not the possession of pleasure. ${ }^{19}$ In the last stanza of "Julian and Maddalo," he experiments

19 See especially the sonnet "Lift not the painting veil", and the late lyrics "When Passion's Trance is Overpast" and "The Flower That Smiles Today". 
with all three steps in the process of desiring, obtaining, and losing, and also with the idea of contenting oneself with uncertainty as a means of putting a memory to rest. To an extent, "Julian and Maddalo," like "Lines Written in the Bay of Lerici," abandons its subject just before the end in order to focus on the consequences of pursuing that subject. Much of what was important in the narrative of the poem is gone by the last stanza; neither Maddalo nor the maniac returns to finish the poem's dialogue. It appears as though, in the final stanza, Shelley's memory of the initial timeframe of the poem has been lying dormant during these "many years" since the poem's principle action and the final stanza is Shelley's attempt to fill in the space between his memory and the present $\left(5^{8} 3\right)$. The problem that arises for Shelley is a version of the problem that he will continue to struggle with throughout his poetry and ultimately identify in "The Triumph of Life:" that night comes before evening. ${ }^{20}$ Shelley returns to the memory too late, and the story that "Julian and Maddalo" set out to tell is over before Shelley finishes it.

The idea that Shelley begins to address at the end of "Julian and Maddalo," that memory can evoke more pain than desiring and losing, takes the form of "wild" thoughts and feelings in his later works. For Shelley, "wild” emotions are fruitless and despairing; to be wild is to rush after something uncontrollably and in vain. The "demon reassum[ing] his throne" just before the finals scene in "Lines Written in the Bay of Lerici" is the return of this type of thought. In one of his shorter lyrics, "When Passion's Trance is Overpast," Shelley wishes for "all wild feelings to "keep some mortal slumber" (3-

20 Christopher Miller calls attention to the fact that "Julian and Maddalo" is set at evening in order to highlight another type of ending: "By situating a lyric at evening, the poet often self-consciously articulates the strangeness of his or her vocation in relation to other ways of being in the world: while other people's work is ending, the poet's has just begun. The Invention of Evening (Cambridge: Cambridge University Press, 2006), p.4. 
4). In this poem, at least, if wild thoughts are calm, and tenderness and truth last, then Shelley "should not weep" (5). This formulation is not possible, however, and Shelley knows this, as this memory of tenderness and truth will be what reawakens wild thoughts in "Lines Written in the Bay of Lerici," and this wildness will overtake everything in "The Triumph of Life."

In "The Triumph of Life," the wild thoughts which shatter tenderness in Shelley's shorter lyric fuel "the wild dance" of those in the triumphal procession ( I 38). Those who dance in front of the car of light are alive with wildness — they "fling their wild arms in air" ( 148 ) — but the car eventually passes over them. When the car rolls over the captives, they do not die, but experience a new form of wildness, in which they strain desperately to reach the car "which leaves them still / Farther behind and deeper in the shade" ( 68 - I69). Unlike the fish, who experience a swift death before they reach the flame, those captives driven wild by the car of light are eventually run down by it:

One falls and then another in the path Senseless, nor is the desolation single,

Yet ere I can say where the chariot hath Past over them ( I 50- I 62).

The captives survive their encounter with the car of light, and so they experience what the fish do not, "the regret that pleasure leaves," and strain to catch it again. 
This image—-the preemptive end, deep night before evening—reappears several times throughout "The Triumph of Life:" when the wise, great, and unforgotten men of whom Rousseau speaks are unable to find truth, he describes them as having been caught by "deep night...ere evening" (2 I 4-2 I 5).

The phrase appears yet again towards the poem's end, when the phantoms bring "ere evening /

Strange night" upon man $(484-487)$. For Shelley, the idea that death ends the joy of life is an overly optimistic one, and one which only applies to the fish. In Shelley's weary reality, life ends the joy of life.

Shelley's conception of life yielding not to death, but to more life is a redoing of Edgar's counterintuitive thought in "King Lear:"

World, world, O world!

But that thy strange mutations make us hate thee, Life would not yield to age. ${ }^{21}$

The surprising fact in "The Triumph of Life" that the rolling car of life does not kill those it passes over, but rather makes them old, echoes the surprising last word of this passage, which we expect to be "death." In both cases, the result should be death; however, what Shelley wishes us to see is how, in "The Triump of Life," "the trunk [can] survive both fruit and flower" and how these "strange mutations" set us in enmity with life ( 124 ).

21 “King Lear" The Norton Shakespeare (New York: W.W. Norton, 1998), 4.1.11-13. 
"The Triumph of Life" does not fit comfortably into any category of endings because its ending is not purposeful. ${ }^{22}$ The poem, which Shelley left unfinished upon his death, and which is usually printed without any punctuation at the end, stops mid-sentence, just as Rousseau begins to answer a question posed by Shelley. ${ }^{23}$ This last question in "The Triumph of Life" recalls his question at the end of "Mont Blanc:"

And what were thou, and earth, and stars, and sea, If to the human mind's imaginings Silence and solitude were vacancy? ( I 42-I 44)

In "The Triumph of Life," Shelley repeats the "if...then" construction of this question: "Then, what is Life?" he asks the form of Rousseau. Rousseau has just described a series of falling masks, which "fell from the countenance / And form of all," and soon the people themselves begin to fall, growing weary of the dance. In fact, Shelley repeats a form of this question four times throughout the poem, but never receives a satisfactory answer: "All hastened onward, yet none seemed to know / Whither he went, or whence he came, or why" (47-48); "And what is this? / Whose shape is that within the car? \& why" ( I 77-I 78); "Whence camest thou and whither goest though? How did thy course begin...and why?” (296-297); "Shew whence I came, and where I am, and why-" (398). Each repetition of this un-

22 Barbara Smith argues that many of the great Romantic fragments (she cites "The Fall of Hyperion" specifically) could not, given the problems inherent in their current form, have been completed at all. Poetic Closure: A Study of How Poems End (Chicago: University of Chicago Press, 1968), p.220.

23 In the Norton Critical Edition, the last two lines of the poem read as follows:

And answered... 'Happy those for whom the fold

Of

Shelley's Poetry and Prose, eds. Donald H. Reiman and Neil Fraistat (New York: W.W. Norton \& Company, 2002). 
answered question is itself a fragmented ending, but the impossibility of an answer that would not be

Shelley's own is both the driving force bind the poem and its downfall.

\section{"The trunk survived both fruit and flower:" Living beyond the end of the poem.}

Shelley's anticlimactic endings reveal how life subverts the desire, as Kermode puts it, "to be-

long to a beginning and an end," either by ending before the "end" we have imagined for ourselves ar-

rives, or by outlasting that "end" and forcing us to realize, once it has passed, that it was a delusion.

Shelley's more conventional endings, like that of "Adonais" (despite the unnerving similarity it bears to

Shelley's own death), operate more or less within a normal temporal system. In "Adonais," Shelley ar-

ticulates a version of this disjointed chronology of loss in relation to his own life. At the time of compos-

ition, Shelley had lost two of his children to illness and two to foster-parents, and was experiencing

poor health as well as negative critical reception: ${ }^{24}$

Why linger, why turn back, why shrink, my Heart?

Thy hopes are gone before; from all things here

They have department; though shouldst now depart! (469-47 I)

In "Adonais," Shelley, a living poet, pays tribute to Keats, a dead poet. At the end of the poem, Shelley imagines his own death and the guiding role that Keats' soul will play in it. This ending's strangeness comes from the fact that Shelley presents his prophecy in the present tense: the familiar elegiac maneuver, in which the living speaker looks forward to a heavenly reunion, takes place at the moment of 
the poem's composition. Nevertheless, the dead are in "Heaven," and the living must die to join them.

The same cannot be said of the captive throng in "The Triumph of Life," who strain to reach the car of life, but are also run down by it.

Another oft-quoted anecdote from Trelawney's Recollections places his genius beyond the limiting grasp of ordinary men; Trelawney reports with characteristic vagueness that "Shelley's words were, 'I always go on until I am stopped, and I never am stopped.” ${ }^{25}$ Again, Trelawney’s anecdote features a poet who awaits an external intervention. To return to the anecdote of Shelley's near-drowning, Trelawney's Shelley sought truth which could only be grasped by casting off the body. In a sense, Shelley's endings feel incomplete because he does not reconcile himself with a stopping point. It would not be enough for Shelley to, as Benjamin puts it, "warm his shivering life with a death he reads about;" it must be Shelley's own death, as in "Adonais," that ends the poem, or some consciousness beyond Shelley’s own. In "Julian and Maddalo," Julian does not share the truth with the "cold world" because he does not have it; it belongs to the impregnable other mind of the unreal Allegra. The same is true of "Mont Blanc" and "The Triumph of Life," in which Shelley poses questions which cannot be answered aloud because the answering voice would have to be his own. Like Trelawney's Shelley in the drowning anecdote, we sense that in another minute he could have found the answer, but he would have had to desert his own body for it.

JULIA TEJBLUM

25 Edward Trelawney, Recollections of the Last Days of Shelley and Byron (Boston: Ticknor and Fields, 1858), p.67. 